Ekasari et al., Afr., J. Infect. Dis. (2018) 12(S): 111-115

https://doi.org/10.2101/Ajid.v12i1S.16

\title{
DETERMINATION OF EFFECTIVE DOSE OF ANTIMALARIAL FROM CASSIA SPECTABILIS LEAF ETHANOL EXTRACT IN PLASMODIUM BERGHEI-INFECTED MICE
}

\author{
Wiwied Ekasari $^{1}{ }^{*}$, Tutik Sri Wahyuni $^{1}$, Heny Arwaty $^{2}$, Nindya T. Putri ${ }^{1}$
}

${ }^{1}$ Departement of Pharmacognosy and Phytochemistry, Faculty of Pharmacy, Airlangga University, Surabaya, Indonesia; ${ }^{2}$ Faculty of Medicine, Airlangga University, Surabaya, Indonesia.

*Corresponding Author E-mail: wiwiedeka@hotmail.com

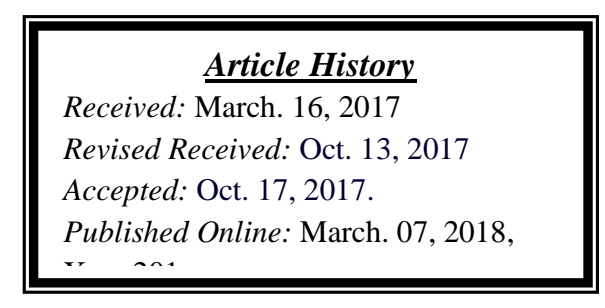

Abstract

Background: The preliminary study on antimalarial activity of the ethanol extract of Cassia spectabilis leaves against Plasmodium berghei has been carried out by in vivo experiment. It was demonstrated that ethanol extract of $C$. spectabilis leaves could inhibit growth of rodent malaria parasite P. berghei by $59.29 \%$ (at a dose of $100 \mathrm{mg} / \mathrm{kg}$ bodyweight). However, further investigation is required to determine an effective dose of the administered extract for a higher inhibitory effect and increasing effectiveness of the extract.

Material and Methods: To determine the effective dose of ethanol extract of $C$. spectabilis leaves, a "4-day suppressive test"of Peter was performed with some modifications. The extract was administered orally to P. bergheiinfected mice in multiple doses (twice and thrice daily) and single dose (once daily) with dose ranging from 50 - 250 $\mathrm{mg} / \mathrm{kg}$ body weight. Antimalarial activities were determined by analyzing suppression of parasitaemia of treated mice.

Results: The results showed that oral administration of the ethanol extract of $C$. spectabilis leaves at dose of $150 \mathrm{mg} / \mathrm{kg}$ bodyweight thrice daily possessed higher inhibition $(62.42 \%)$ compared to those twice daily $(52.58 \%)$ and once daily $(46.25 \%)$.

Conclusion: These results suggested that ethanol extract of $C$. spectabilis is promising candidate for development of antimalarial drugs. The effective dose of the ethanol extract is $150 \mathrm{mg} / \mathrm{kg}$ bodyweight with thrice administration daily.

Keywords: Cassia spectabilis, antimalarial, Plasmodium berghei, in vivo

\section{Introduction}

Traditional medicines provide for about $80 \%$ of health care in world populations, especially in the developing countries (Bodeker and Kronenber, 2002). In addition, plant-derived compounds have played an important key role in drug discovery. Several plants including their isolated compounds have been reported to inhibit malaria parasite (Oliveira, 2009).

Malaria is currently a public health concern in many countries due to factors such as the emerge of resistance, poor hygienic conditions, poorly managed vector control programs and no available approved vaccines (Onguene et al., 2013).

Malaria is a disease that is transmitted through the bite of a female Anopheles mosquito, which is infected by protozoa of genus Plasmodium. It is still endemic in most parts of Indonesia (WHO, 2015). Elyazar et al., 2011 summarized the distribution of P. Palciparum, P.vivax, P. malariae, and $P$. ovale among Indonesian population during the year of 1900-2009 was 5.8; 4.9; 0.2 and $0.005 \%$ respectively. Those data showed that $P$. falciparum was the highest cause among the reported infection cases. The morbidity and mortality on malaria cases in Indonesia are routinely under-reported. The WHO estimated that there were 2.5 million cases of malaria in Indonesia in 2006 and over 3000 deaths had occurred in the year of 2006 (Elyazar et al., 2011).

Malaria eradication program has been carried out to suppress the morbidity and mortality caused by malaria, including early diagnosis, prompt treatment, proper surveillance and vector control. However, it also impacted on the increasing of drug resistance cases, (WHO, 2016). A new antimalarial drug to overcome such resistance is absolutely required.

Medicinal plants are potential resources for the search of antimalarial agents. Plants which are belonging to genus of Cassia have been reported possess strong inhibition against malaria parasite (Abdulrazak et al., 2015; Ekasari et al., 2009; Morita et al.,2007). 
Cassia Linn. is a major genus of Caesalpiniaceae family. It has 600 species and some of which are widely distributed worldwide especially in tropical countries such as India (Dave and Ledwani, 2012; Viegas et al, 2004). They are also widely distributed in tropical and subtropical regions and have been used as traditional folk medicine, particularly for treatment of fever and malaria (Dave and Ledwani, 2012).

Other study reported on the chemical constituents of genus Cassia. The secondary metabolites of $C$. spectabilis, C. siamea, C. fistula, $C$. biflora and $C$. hirsute have been identified including alkaloids, tannins, saponins, flavonoids, carbohydrates, proteins, steroids, terpenoids, cardiac glycosides and phlobatannins (Usha and Bopaiah, 2011)

Our previous study has been reported on one of the plants from the genus Cassia in Indonesia, i.e. C. siamea that exhibited antimalarial activity. The isolated compound, namely Cassiarin A, revealed to effectively inhibit the growth of malaria parasites with $\mathrm{IC}_{50}$ value of $0.005 \mu \mathrm{g} / \mathrm{mL}$ and $\mathrm{ED}_{50}$ value of $12.17 \mathrm{mg} / \mathrm{kg}$ body weight (Morita et al, 2007; Ekasari et al., 2009).

Our previous screening on antimalarial activities of different nine plant species from the genus of Cassia showed that $C$. spectabilis produced the highest inhibition against malaria parasite (Ekasari et al, 2015). In vitro analysis revealed that methanol extract of leaves from $C$. spectabilis showed the strongest antimalarial activity against P. falciparum with $\mathrm{IC}_{50}$ value of $2.66 \mu \mathrm{g} / \mathrm{mL}$. Moreover, its ethanolic extract also inhibits the growth of the P.berghei in vivo by $59.29 \%$ (at dose of $100 \mathrm{mg} / \mathrm{kg}$ bodyweight). Further investigation on posible compounds which contributed to its antimalarial activities, revealed that only leaves of $C$. spectabilis possess an alkaloid compounds (Ekasari et al., 2009). However, other study also reported the isolated compounds from C. spectabilis including beta-sitosterol, betulinic acid, caffein, dihidroksi calamenen, 1,8-dihydroksi-3-metyl-6-metoksi antraquinon, friedelin, oleanolic acid, alkaloid piperidin, spectaline, stigmasterol; 1,3,8-trihidroksi-2-methylantraquinone and ursolic acid (Subramananion et al., 2012).

Determination of an effective dose that causing a higher inhibitory effect is needed before the extract can be used as an antimalarial drug. First step is to define $\mathrm{ED}_{50}$ value of the ethanolic extract of $C$. spectabilis leaves against $P$. berghei in mice by giving the $P$. berghei-infected mice with the extract based on Munos et al (2000). Further, based on this value the extract will be given in a single and multiple doses. The multiple doses are given to extend the therapeutic activity of the extract. Plasma level of the drug is maintained as therapeutic range to achieve its maximal effectivity, therefore, multiple doses are given in order to maintain its plasma level relatively constant. The rules of drug dosing is to give the ideal plasma level without any fluctuation and excesssive accumulation of the drug (Shargel et al., 2005).

\section{Materials and Methods Plant Material}

The leaves of $C$. spectabilis were collected from Purwodadi Botanical Garden, East Java, Indonesia and specimen was deposited as the herbarium (Number : 525/IPH.3.04/HM/IV/2015)

\section{Rodent's parasite}

The chloroquine sensitive $P$. berghei ANKA strain was obtained from Institute of Biomolecular Eijkmann, Jakarta, Indonesia. Mice were maintained at Malaria Laboratorium, Faculty of Pharmacy, Airlangga University, Indonesia. The percentage of parasitaemia of mice donor was examined through gram staining of mice-infected blood. Blood was collected from the mice with high parasitaemia and deposited for the use of next infection.

Inoculum of erythrocytes infected with P.berghei was prepared by determining the percentage parasitaemia of mice donor and diluting the blood with alceivers solutions with predetermined proportion. The mice were infected intraperitonially with $200 \mu \mathrm{L}$ of $5 \%$ parasite-containing blood from frozen deposits. Once the percent of parasitaemia reached $20 \%$, the mice blood was taken intracardially and diluted with PBS up to $1 \%$ parasitaemia. The test mice were further infected with $200 \mu \mathrm{L}$ of this parasite-containing blood with 1\% parasitaemia (Widyawaruyanti et al., 2014).

\section{Animals}

Adult male Balb-C mice with 20-30 g bodyweight were obtained from Pusat Veterinaria Farma (PUSVETMA) Surabaya. The mice were fed with mice pellet diet and given free access to clean drinking water. The animals allowed to acclimatize for two weeks before treated. The permission and approval for animal studies were obtained from Faculty of Veterinary Medicine, Airlangga University.

\section{Preparation of Extract}

The leaves of $C$. spectabilis were cleaned, shade dried for four days and pulverized to produce powder. One kilogram of the dried leaf powder was extracted with $5 \mathrm{~L}$ of $90 \%$ ethanol using maceration method. 


\section{Antimalarial Activity}

Antimalarial activities were performed by in vivo experiment in mice. In order to determine $\mathrm{ED}_{50}$, animals were divided into seven groups of five mice, one was negative control group and six were treated groups. The negative control group was given CMC Na 0,5\% once a day orally, and treated groups were fed with suspension of $90 \%$ ethanol extract of $C$. spectabilis leaves with the dose of 50,75, 100, 150, 200 and $250 \mathrm{mg} / \mathrm{kg}$ body weight of mice once a day orally.

Further investigation to determine the effective dose of extract was also performed. Two kind of experiments were conducted in parallel. First, the ethanol extract of C.spectabilis leaves was administered in multiple doses (twice and thrice daily). Second, it was administered in single dose (once daily) orally at a dose of $150 \mathrm{mg} / \mathrm{kg}$ of body weight.

Antimalarial activity of ethanol extract of $C$. spectabilis leaves were conducted by4-day suppressive test of Peters (Phillipson and Wright, 1991). Each mouse was inoculated intraperitonially on the first day (day 0/ D0) with 0.2 $\mathrm{ml}$ of $P$. berghei-infected blood (1\%), and followed by treatment of the malarial- infected mouse with ethanol extract of C. spectabilis in concentration of $50,75,100,150,200$ or $250 \mathrm{mg} / \mathrm{kg}$ bodyweight. The extract was administered orally for four consecutive days.

On the fourth day after treatment (D4), the percentage of parasitaemia in $P$. berghei-infected mouse was evaluated by collecting blood from the tail of mice, and the parasitaemia was examined by gram staining. Parasitaemia level was determined by counting the number of parasite-infected erythrocytes per 3000 erythrocytes, and the $\mathrm{ED}_{50}$ was calculated by probit analysis. The $\mathrm{ED}_{50}$ representing $50 \%$ suppresion of parasite when it is compared to untreated control.

Average percentage of parasite's inhibition was calculated as following :

$100 \%-\left(\frac{\mathrm{X}_{\mathrm{e}}}{\mathrm{X}_{\mathrm{k}}} \times 100\right)$

$\mathrm{X}_{\mathrm{e}}=\%$ parasitaemia growth of the treated

$\mathrm{X}_{\mathrm{k}}=\%$ parasitaemia growth of negatif contro]

\section{Results}

The results of in vivo antimalarial activity of ethanol extract of $C$. spectabilis leaves against $P$. berghei is presented in Table 1, Table 2 and Table 3. The percentage of parasitaemia was observed from day 0 to day 4 post treatment (Table 1).

Table 1: The percentage parasitaemia value of mice infected-P. berghei treated with ethanol extract of $C$. spectabilis leaves perorally

\begin{tabular}{cccccc}
\hline \multirow{2}{*}{$\begin{array}{c}\text { Sample }(\mathrm{mg} / \mathrm{kg} \\
\text { body weight) }\end{array}$} & $\mathrm{D}_{0}$ & $\mathrm{D}_{1}$ & $\mathrm{D}_{2}$ & $\mathrm{D}_{3}$ & $\mathrm{D}_{4}$ \\
\hline & $1.22 \pm 0.71$ & $5.24 \pm 2.52$ & $5.59 \pm 3.56$ & $16.54 \pm 4.28$ & $21.77 \pm 4.83$ \\
Neg. control & $1.57 \pm 2.16$ & $3.28 \pm 2.27$ & $6.57 \pm 3.23$ & $11.15 \pm 2.56$ & $15.74 \pm 3.14$ \\
50 & $2.11 \pm 1.47$ & $3.83 \pm 2.94$ & $6.02 \pm 3.54$ & $10.93 \pm 4.05$ & $15.85 \pm 4.61$ \\
75 & $1.88 \pm 1.57$ & $4.35 \pm 3.85$ & $7.49 \pm 6.32$ & $10.48 \pm 6.27$ & $13.47 \pm 6.40$ \\
100 & $1.30 \pm 1.23$ & $4.34 \pm 2.60$ & $5.73 \pm 2.69$ & $7.11 \pm 2.18$ & $11.29 \pm 3.21$ \\
150 & $1.26 \pm 0.75$ & $3.95 \pm 1.39$ & $4.69 \pm 0.99$ & $8.16 \pm 3.83$ & $9.89 \pm 2.70$ \\
200 & $0.51 \pm 0.40$ & $2.51 \pm 0.99$ & $4.64 \pm 0.96$ & $5.92 \pm 1.70$ & $6.90 \pm 1.67$ \\
250 &
\end{tabular}

Data were obtained from average of 5 replications. $\mathrm{D}_{0}-\mathrm{D}_{4}$ : Observation of percentage parasitaemia from day 0 (D0) until Day 4 (D4) post treatment.

The percentage parasitaemia of negative control was dramatically increased after three day (D3) and four day (D4) post treatment with parasitaemia level of $16.54 \pm 4.28 \%$ and $21.77 \pm 4.83 \%$, respectively. A significant reduction of parasitaemia was observed by treatment at dose of $150 \mathrm{mg} / \mathrm{kg}$ body weight in D4 which showed percentage inhibitory of $51.38 \pm 12.58 \%$ (Table 2). The result indicated that the dose of $150 \mathrm{mg} / \mathrm{kg}$ bodyweight of extract possess strong inhibition against $P$. berghei.

Tabel 2: The average percentage of growth and the inhibition of mice infected-P. Berghei treated with ethanol extract of . spectabilis leaves perorally.

\begin{tabular}{ccc}
\hline $\begin{array}{c}\text { Sample } \\
(\mathrm{mg} / \mathrm{kg} \text { body weight })\end{array}$ & $\begin{array}{c}\text { Average percentage of } \\
\text { growth }\end{array}$ & $\begin{array}{c}\text { ED }_{50} \\
\text { Average percentage inhibition }\end{array}$ \\
\hline Negative control & $20.55 \pm 5.01$ & - \\
50 & $14.17 \pm 3.25$ & $31.05 \pm 15,82$ \\
75 & $13.74 \pm 3.55$ & $33.13 \pm 17,26$ \\
100 & $11.59 \pm 6.07$ & $43.60 \pm 29,56$ \\
150 & $9.99 \pm 2.59$ & $51.38 \pm 12,58$ \\
200 & $8.62 \pm 2.18$ & $58.04 \pm 10,59$ \\
250 & $6,39 \pm 1.82$ & $68,91 \pm 8,84$ \\
\hline
\end{tabular}

Data were obtained from 5 replications. 
Further analysis to determine the effective dose showed that multiple dose administration daily produced higher inhibition with percentage inhibitory of $52.58 \pm 7.18$ and $62.42 \pm 1,62 \%$, (twice and thrice daily respectively). Those were higher than the single administration which was $46.25 \pm 3.83 \%$ (Table 3 ).

Table 3: In vivo inhibition of mice infected-P. berghei treated with ethanol extract of Cassia spectabilis leaves at single dose $(150 \mathrm{mg} / \mathrm{kg}$ body weight $)$ and multiple dose $(2 \times 150 \mathrm{mg} / \mathrm{kg}$ body weight and $3 \times 150 \mathrm{mg} / \mathrm{kg}$ body weight $)$ during 4 days

\begin{tabular}{|c|c|c|c|c|c|c|c|}
\hline $\begin{array}{l}\text { Sample } \\
\mathrm{mg} / \mathrm{kg} \\
\text { bodyweight }\end{array}$ & Rep & D0 & D4 & $\begin{array}{l}\text { Percentage } \\
\text { of growth }\end{array}$ & $\begin{array}{l}\text { Average of } \\
\text { percentage } \\
\text { growth }\end{array}$ & $\begin{array}{l}\text { percentage } \\
\text { inhibition }\end{array}$ & $\begin{array}{l}\text { Average of } \\
\text { percentage } \\
\text { inhibition }\end{array}$ \\
\hline Negative & 1 & 1.25 & 8.28 & 7.03 & $7.03 \pm 1.18$ & - & - \\
\hline \multirow[t]{5}{*}{ control } & 2 & 0.55 & 10.07 & 9.52 & & - & \\
\hline & 3 & 2.48 & 8.84 & 6.36 & & - & \\
\hline & 4 & 1.29 & 8.32 & 7.03 & & - & \\
\hline & 5 & 0.77 & 7.01 & 6.24 & & - & \\
\hline & 6 & 1.28 & 7.28 & 6.00 & & - & \\
\hline \multirow[t]{6}{*}{150} & 1 & 2.17 & 6.37 & 4.20 & $3.78 \pm 0.27$ & 40.26 & $46.25 \pm 3.83$ \\
\hline & 2 & 1.40 & 5.35 & 3.95 & & 43.81 & \\
\hline & 3 & 1.32 & 5.17 & 3.85 & & 45.23 & \\
\hline & 4 & 2.25 & 5.68 & 3.43 & & 51.21 & \\
\hline & 5 & 1.75 & 5.53 & 3.78 & & 46.23 & \\
\hline & 6 & 1.62 & 5.08 & 3.46 & & 50.78 & \\
\hline \multirow[t]{6}{*}{$2 \times 150$} & 1 & 3.12 & 5.57 & 2.45 & $3.33 \pm 0.50$ & 65.15 & $52.58 \pm 7.18$ \\
\hline & 2 & 1.54 & 4.81 & 3.27 & & 53.49 & \\
\hline & 3 & 0.94 & 5.13 & 4.19 & & 40.10 & \\
\hline & 4 & 1.91 & 5.22 & 3.31 & & 52.92 & \\
\hline & 5 & 1.61 & 5.04 & 3.43 & & 51.21 & \\
\hline & 6 & 1.83 & 5.16 & 3.33 & & 52.63 & \\
\hline \multirow[t]{6}{*}{$3 \times 150$} & 1 & 1.94 & 5.10 & 3.16 & $2,64 \pm 0.29$ & 55.05 & $62.42 \pm 1,62$ \\
\hline & 2 & 1.66 & 4.50 & 2.66 & & 62.16 & \\
\hline & 3 & 1.73 & 4.36 & 2.63 & & 62.59 & \\
\hline & 4 & 0.99 & 3.58 & 2.59 & & 63.16 & \\
\hline & 5 & 1.62 & 4.42 & 2.62 & & 62.73 & \\
\hline & 6 & 1.89 & 4.08 & 2.19 & & 68.85 & \\
\hline
\end{tabular}

\section{Discussion}

Medicinal plants are potential resources for antimalarial agent. Preliminary study of C. spectabilis reported the antimalarial activities of this plant and proved to be a promising candidate for antimalarial agent. Further analysis was conducted in this study to determine the effectiveness of ethanol extract of $C$. spectabilis in the animal test.

In vivo analysis to $P$. berghei-infected mice was conducted by adopting method of Munoz et al. (2000) which applied some dose modification. The $P$. berghei-infected mice were treated with $C$. spectabilis extract in dose range of $50-250 \mathrm{mg} / \mathrm{kg}$ body weight. The results showed dose dependent mode of inhibition and 50\% inhibition was obtained by the dose of $\leq 150 \mathrm{mg} / \mathrm{kg}$ bodyweight (Table 1 and 2). The dose of $250 \mathrm{mg} / \mathrm{kg}$ produced the highest inhibitory (68.91\%), while those that received 200 and $150 \mathrm{mg} / \mathrm{kg}$ body weight exhibited inhibitory of $58.04 \pm 10,59 \%$ and $51.38 \pm 12,58 \%$, respectively (Table 2). These results suggested that ethanol extract of $C$. spectabilis leaves can be categorized as good antimalarial activity, with $>50 \%$ inhibitory effect achieved at dose of $250 \mathrm{mg} / \mathrm{kg}$ (Munoz et al., 2000). Other study (Bantie et al.,2014), classified extracts which have more than $50 \%$ percentage inhibitory value in in vivo antimalarial test with doses of 500, 250 and $100 \mathrm{mg} / \mathrm{kg}$ of body weight as moderate, good and excellent activity, respectively.

According to those classifications, the activity of ethanol extract of $C$. spectabilis leaves can be classified as good antimalarial activity. The $\mathrm{ED}_{50}$ of ethanol extract of $C$. spectabilis was $131.5 \mathrm{mg} / \mathrm{kg}$ body weight (Table 2). Therefore, the dose of $150 \mathrm{mg} / \mathrm{kg}$ body weight was used to determine the effectiveness as antimalarial agent.

The study was continued by investigating the administration of ethanol extract of $C$. spectabilis in multipledose and single dose with dose of $150 \mathrm{mg} / \mathrm{kg}$ body weight. The result showed that the growth percentage of $P$. berghei for multiple doses ( 2 or 3 times a day) were lower than single dose. The lowest growth shown for thrice daily. This means that the extract administered in multiple doses is more effective inhibiting the growth of the parasite compared to single dose. Multiple doses administration could maintain the optimal or therapeutic concentration in blood and inhibit parasite in the various stage of parasite's life cycle. This provides availability of drugs in blood longer so that the therapeutic effect can be maintained. 


\section{Conclusion}

C. spectabilis is potential candidate for antimalarial agent. The antimalarial effective dose of ethanol extract of C. spectabilis leaves in P.berghei-infected mice is $150 \mathrm{mg} / \mathrm{kg}$ bodyweight with thrice daily administration.

Conflict of Interest: The authors declare that they have no conflict of interest.

Acknowledgements: This research was funded by Directorate of Higher Education Indonesia (DIKTI), 2016.

\section{References}

1. Abdulrazak N, Asiya UI, Usman NS, Unata IM, Farida A, (2015). Anti-plasmodial activity of ethanolic extract of root and stem back of Cassia sieberiana DC on mice, Journal of Intercultural Ethnopharmacology Apr-jun; 4 (2) : 96-101

2. Alaíde B. Oliveira, Maria Fâni Dolabela' Fernão C. Braga' Rose L.R.P. Jácome' Fernando P. Varotti' Marinete M. Póvoa (2009). Plant-derived antimalarial agents: new leads and efficient phythomedicines. Part I. Alkaloids. Anais da Academia Brasileira de Ciências. Vol.81. 4.

3. Bantie L, Assefa S, Teklehaimanot T, Engidawork E. (2014). In vivo antimalarial activity of the crude leaf extract and solvent fractions of Croton macrostachyus Hocsht (Euphorbiaceae) against P. berghei in mice. BMC Complementary and Alternatif Medicine 14:79.

4. Bodeker G, Kronenberg F. (2002). A Public health agenda for traditional, complementary, and alternative medicine. American Journal of Public Health. 92:1582-91.

5. Dave H and Ledwani L. (2012). A Review on anthraquinones isolated from Cassia species and their applications. Indian Journal of Natural Products and Resources. 3: 291-319.

6. Elyasar IRF, Hay SI, Baird JK, Malaria distribution, prevalence, drug resistance and control in Indonesia. (2011), Advances in Parasitology.74:41-175

7. Ekasari W, Widyawaruyanti W, Zaini NC, Syafruddin, Honda T, and Morita H. (2009). Antimalarial activity of cassiarin a from the leaves of Cassia siamea.Heterocycles.78: 1831-1836.

8. Ekasari W, Wahyuni TS, Satyo Y RA. (2015). Potential anti-malaria and microscopic- phytochemical examination of leaves of some plants Cassia Genus. Journal Farmasi dan Ilmu Kefarmasian Indonesia. 2:48-52.

9. Morita H, Oshimi S, Hirasawa Y, Koyama K, Honda T, Ekasari W, Indrayanto G and Zaini NC. (2007). Cassiarin A and B, novel antiplasmodial alkaloids from Cassia siamea. Organic Letters. 9: 3691-3693.

10. Munoz V, Sauvin M, Bourdy G, Callapa J, Rojas I, Vargas L, Tae A, Deahro E. (2000). The search for natural bioactive compounds through a multidisciplinary approach in Bolivia. Part II. Antimalarial activity of some plants used by Mosetene Indians. Journal Ethnopharmacology. 69:139-155

11. Onguene PA, Ntie -Kang F, Lifongo LL, Ndom JC, Sippl W, Mbaze LM. (2013). The potential of anti-malarial compounds derived from African medicinal plants. Part I: A pharmacological evaluation of alkaloids and terpenoids, Malaria Journal.12:449

12. Phillipson JD and Wright CW. (1991). Antiprotozoal agents plant sources. Planta Medica. 57: 53 - 59

13. Shargel L, Wu-Pong S, Yu AB. (2005). Applied biopharmaceutics and pharmacokinetics. $5^{\text {th }}$.Ed. Boston:Mc Graww Hill.

14. Subramananion L. Jothy, Torey A, Darah I, Choong Y.S, Saravanan D, Chen Yeng, Latha L.Y, Deivanai S, Sasidharan S. (2012). Cassia spectabilis (DC) Irwin et Barn: A promising traditional herb in health improvement.Molecules.17: 10292-10305.

15. Usha Veerachari, Bopaiah A.K. (2011). Preliminary phyto-chemical evaluation of the leaf extract of five Cassia species. Journal of Chemical and Pharmaceutical Research. 3: 574-583

16. Viegas, J.R.C.; Bolzani, V.S.; Furlan, M. Barreiro, EJ.; Young, M.C.M.; Tomazela D.M.; Eberlin, M.N. (2004). Further bioactive piperidine alkaloids from the flowers and green fruits of Cassia spectabilis. Journal of Natural Products.67: 908-910.

17. WHO: World malaria report. (2015). Geneva: World Health Organization, available from http://who.int./malaria/publications/country-profiles/profile idh_en.pdf (accessed on September 27, 2016).

18. WHO: Malaria Case Management: Operation manual, available from http: www.who.int/malaria/publications/atoz/malaria_case_management_operation_manual.pdf (accessed on September 27, 2016).

19. Widyawaruyanti A, Asrory M, Ekasari W, Setiawan D, Radjaram A, Tumewu L, Hafid A.F. (2014). In vivo antimalarial activity of Andrographis paniculata tablet. Procedia Chemistry.13:101-104. 